\title{
Tingkat Kenyamanan Hunian Berdasarkan Kondisi Fisik Rusunawa Blok A dan Blok B Jalan Kom Yos Sudarso Pontianak
}

\author{
Riska Aprilia Ayuningtyas ${ }^{\text {a }}$ \\ a Universitas Tanjungpura Pontianak, Indonesia \\ E-mail Korespondensi: riska054@gmail.com
}

\begin{abstract}
Usaha pemerintah dalam memenuhi kebutuhan perumahan di kota - kota besar dengan tingkat kepadatan yang tinggi adalah dicanangkannya kebijakan pembangunan rumah susun. Tujuan pembangunan rumah susun adalah memenuhi kebutuhan rumah layak huni bagi masyarakat berpenghasilan rendah dan menciptakan lingkungan yang selaras dan seimbang. Namun demikian, kendala yang dihadapi dalam pembangunan rumah susun adalah kualitas bangunan berada di bawah standar serta penyediaan sarana dan prasarana kurang seimbang. Salah satu rumah susun di Kota Pontianak adalah Rumah Susun yang terletak di Kelurahan Sui Beliung, Kecamatan Pontianak Barat. Tujuan penelitian ini adalah untuk mengidentifikasi tingkat kenyamanan hunian berdasarkan kondisi fisik rumah susun. Metode yang digunakan dalam mencapai sasaran penelitian ini adalah dengan teknik observasi dan penyebaran kuesioner. Metode analisa yang digunakan adalah analisis deskriptif kualitatif yaitu penilaian observatif guna mengidentifikasi kondisi fisik hunian rumah susun, analisis skoring untuk mengidentifikasi persepsi penghuni terhadap kondisi fisik rumah susun dan untuk mengetahui kategori tingkat kenyamanan hunian rumah susun. Hasil penelitian menunjukkan nilai tingkat kenyamanan hunian berdasarkan kondisi fisik rusunawa adalah 8 yang masuk dalam kategori nyaman.
\end{abstract}

Keywords: tingkat kenyamanan, kondisi fisik, persepsi, rumah susun

\begin{abstract}
The government's effort to meet housing needs in big cities with high density is implementing a policy to build flats. Building flats is to meet the needs of livable houses for low-income people and create a harmonious and balanced environment. However, the obstacles faced in the construction of flats are that the buildings' quality is below standard and the provision of facilities and infrastructure is not balanced. One of Pontianak City's flats is located in Sui Beliung Village, West Pontianak District. This study aims to identify the level of residential comfort based on the physical condition of the apartment. The method used in achieving the objectives of this study is the observation technique and distributing questionnaires. The analytical method used is descriptive qualitative analysis, namely observative assessment to identify the apartment occupancy's physical condition, scoring analysis to identify the occupants' perceptions of the apartment's physical condition, and determining the category of the level of residential comfort in the apartment. The results showed that the value of the level of residential comfort based on the physical conditions of the flat is 8 which is in the comfortable category.
\end{abstract}

Keywords: comfort level, physical condition, perception, flats

How to cite (APA 6th Style):

Ayuningtyas, Riska Aprilia. (2021). Tingkat Kenyamanan Hunian Berdasarkan Konfisi Fisik Rusunawa Blok A dan Blok B Jalan Kom Yos Sudarso Pontianak, 2(1), 41-49. doi: 10.26418/uniplan.v2i1.45887

\section{PENDAHULUAN}

Kota Pontianak merupakan Ibukota Provinsi Kalimantan Barat yang memiliki jumlah penduduk sebanyak 637.723 jiwa pada tahun 2018 dan akan semakin bertambah setiap tahunnya (Badan Pusat Statistik Kota Pontianak, 2018). Lebih lanjut lagi dijelaskan bahwa Upah Minimum Regional (UMR) di Kota Pontianak sebesar Rp 2.318.000 per bulan yang diterima oleh pekerja dan buruh yang mana sudah diputuskan melalui Penetapan Surat Keputusan Gubernur Kalimantan Barat nomor 
579/DISNAKERTRANS/2018 tentang UMK Tahun 2019. Di tahun 2019 terdapat perubahan aturan terkait rumah subsidi type 36 , Kementerian PUPR menyatakan aturan tersebut akan diberlakukan pada bulan Juli 2019. Kementerian Keuangan telah menerbitkan PMK Nomor 81/PMK.010/2019 yang mana disebutkan untuk aturan rumah subsidi tahun 2019 untuk wilayah Kalimantan ditetapkan sebesar Rp153.000.000. Hal ini menunjukkan bahwa pendapatan minimal yang didapat kurang mencukupi kehidupan sehari-hari bahkan untuk membeli rumah. Oleh karena itu, pemerintah Kota Pontianak membangun rusunawa (rumah susun sederhana sewa) dengan harga terjangkau bagi masyarakat berpenghasilan rendah dalam merealisasikan program pembangunan 1.000 menara rumah susun.

Sebagai ibukota dari Provinsi Kalimantan Barat, Kota Pontianak memiliki tingkat kepadatan yang cukup tinggi menurut data Badan Pusat Statistik (BPS) Kota Pontianak. Kepadatan Kota Pontianak pada tahun 2018 memiliki 5.915 jiwa per kilometer persegi sehingga diberlakukan juga kebijakan pembangunan rumah susun sebagai alternatif pemenuhan kebutuhan rumah untuk masyarakat golongan menengah ke bawah. Di Kota Pontianak terdapat 3 rumah susun yang mana 1 rumah susun berlokasi di Kecamatan Pontianak Selatan tepatnya di Jl. Harapan Jaya dan 2 rumah susunnya lagi berlokasi di Kecamatan Pontianak Barat tepatnya di Jl. Nipah Kuning Dalam dan Jl. Kom Yos Sudarso. Dalam penelitian ini penulis mengambil studi kasusnya di rumah susun yang berlokasi di Jl. Kom Yos Sudarso karena rumah susun tersebut merupakan rumah susun yang paling tua yang ada di Kota Pontianak.

Pembangunan rumah susun ini adalah untuk menangani masalah kekumuhan di wilayah sekitar daerah aliran sungai (DAS) Kapuas. Namun, pada kenyataannya rumah susun ini terkesan kumuh. Lokasi penelitian difokuskan pada 2 (dua) massa bangunan Rumah Susun Sederhana Sewa (rusunawa) yaitu Blok A dan Blok B yang terletak di Jalan Kom Yos Sudarso Kelurahan Sungai Beliung, Kecamatan Pontianak Barat, Kota Pontianak. Kedua bangunan rumah susun ini dibangun pada tahun 2008 dan diresmikan pada tahun 2011, seiring berjalannya waktu pada tahun 2012 rumah susun akhirnya dibuka dan dihuni untuk masyarakat menengah ke bawah. Rumah Susun Sederhana Sewa (rusunawa) berdiri di atas tanah dengan luas $3.186 \mathrm{~m}^{2}$ dengan tinggi bangunan 5 (lima) lantai.

Jika dikaitkan antara keberadaan rumuh susun dengan standar rumah yang layak huni, terlihat bahwa beberapa faktor penentu kelayakan bangunan rumah tidak terpenuhi, salah satunya yaitu adalah tidak terdapatnya fasilitas perniagaan atau perbelanjaan dan fasilitas olahraga. Dampak dari hal tersebut yaitu penghuni harus berbelanja di luar dari rusunawa, secara otomatis penghuni rumah susun tidak nyaman dan penghuni yang ingin berolahraga hanya bisa memanfaatkan halaman rumah susun untuk berolahraga. Berdasarkan permasalahan di atas, maka dilakukan studi untuk Mengidentifikasi tingkat kenyamanan hunian berdasarkan kondisi fisik Rumah Susun Sederhana Sewa (rusunawa) sehingga dapat diketahui aspek apa saja yang perlu dipertimbangkan dalam membangun rumah susun untuk masa yang akan datang.

\section{DATA DAN METODOLOGI}

Ruang lingkup materi yang digunakan dalam penelitian ini disesuaikan dengan kajian pustaka yang berkaitan dengan tema penelitian. Adapun ruang lingkup materi (tabel 1) adalah sebagai berikut:

1. Persepsi masyarakat penghuni rumah susun terhadap kondisi fisik rumah susun, meliputi penilaian masyarakat terhadap kondisi fisik rumah susun.

2. Tingkat kenyamanan hunian rumah susun, meliputi: penilaian terhadap kondisi fisik hunian berdasarkan observasi dan penilaian (persepsi) penghuni terhadap kondisi fisik rumah susun.

Tabel 1. Variabel dan Indikator

\begin{tabular}{lll}
\hline \multicolumn{1}{c}{ Sasaran } & \multicolumn{1}{c}{ Variabel } & \multicolumn{1}{c}{ Indikator } \\
\hline Persepsi Penghuni & Menilai & Penilaian Penghuni \\
Terhadap Kondisi Fisik & Lingkungan & terhadap lingkungan \\
Hunian Rumah Susun & Fisik & fisik Rumah Susun : \\
& & a. Sangat Nyaman \\
& & b. Nyaman \\
& & c. Cukup Nyaman \\
\hline
\end{tabular}




\begin{tabular}{lll}
\hline & & $\begin{array}{l}\text { d. Tidak Nyaman } \\
\text { e. Sangat Tidak Nyaman }\end{array}$ \\
\hline $\begin{array}{l}\text { Merumuskan Tingkat } \\
\begin{array}{l}\text { Kenyamanan Hunian } \\
\text { Berdasarkan Kondisi Fisik } \\
\text { dan Persepsi Penghuni }\end{array}\end{array}$ & $\begin{array}{l}\text { Tingkat } \\
\text { Kenyamanan }\end{array}$ & - Kondisi fisik rumah susun \\
\hline
\end{tabular}

Sumber : Peneliti, 2020

Sedangkan pada ruang lingkup lokasi yang dibahas yaitu alasan pemilihan lokasi dan batasan wilayah penelitian. Pemilihan lokasi penelitian ini disesuaikan dengan judul penelitian dan kondisi lokasi penelitian. Rumah Susun Sederhana Sewa (rusunawa) dijadikan sebagai lokasi penelitian karena tujuan pembangunan rumah susun ini adalah untuk menangani masalah kekumuhan di wilayah sekitar daerah aliran sungai (DAS) Kapuas.

Namun, pada kenyataannya rumah susun ini terkesan kumuh dan berdesak-desakan antara penghuni satu dengan yang lainnya. Lokasi penelitian difokuskan pada 2 (dua) massa bangunan Rumah Susun Sederhana Sewa (rusunawa) yaitu Blok A dan Blok B yang terletak di Jalan Kom Yos Sudarso Kelurahan Sungai Beliung (gambar 1), Kecamatan Pontianak Barat, Kota Pontianak. Rumah Susun Sederhana Sewa (rusunawa) berdiri di atas tanah dengan luas $6.145 \mathrm{~m}^{2}$ dengan tinggi bangunan 5 (lima) lantai. Lokasi yang memang merupakan daerah peruntukan untuk perumahan tersebut telah mendapat izin mendirikan bangunan oleh Pemerintah Kota pontianak melalui Surat Ketetapan Walikota Pontianak mengenai Izin Mendirikan Bangunan No. 641/493/S/RG/2010-2860s/d2861/BP2T-2010.

Variabel penelitian yang digunakan dalam penelitian ini mengacu pada sasaran yang akan dicapai dan berdasarkan landasan teori terkait dengan tema penelitian yaitu tingkat kenyamanan hunian berdasarkan kondisi fisik hunian.

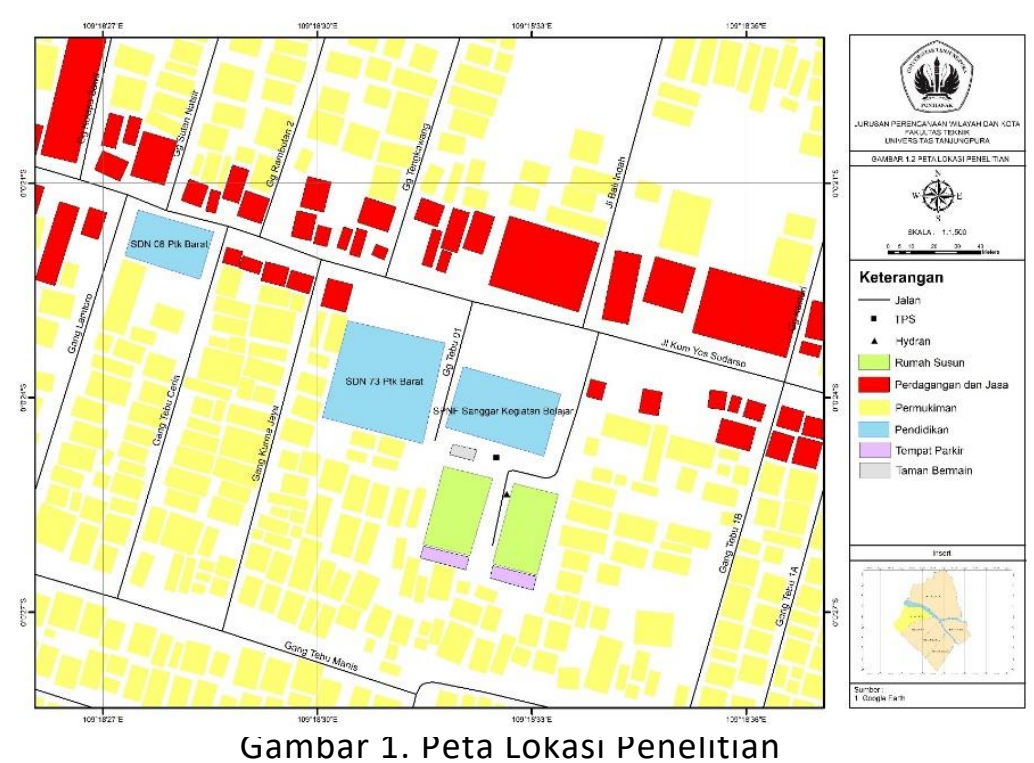

Populasi dalam penelitian ini adalah masyarakat yang menghuni Rumah Susun Sederhana Sewa (rusunawa) yang berjumlah 102 KK, dimana 1 kamar terdiri dari 1 KK. Sedangkan sampel adalah bagian dari jumlah dan karakteristik yang dimiliki oleh populasi (Sugiyono, 2011). Sampel yang diambil dalam penelitian ini adalah sebanyak 51 penghuni rumah susun. Jumlah sampel diambil berdasarkan rumus Slovin. Maka populasi $\mathrm{N}=102$ dengan asumsi tingkat kesalahan $(\mathrm{e})=10 \%$, maka jumlah sampel yang harus digunakan dalam penelitian ini. 


$$
\mathrm{n}=\frac{N}{1+n(e)^{2}}=\frac{102}{1+102(0,1)^{2}}=50,49 \text { dibulatkan menjadi } 51 \text { orang. }
$$

Jadi dari perhitungan diatas, untuk mengetahui ukuran sampel dengan tingkat kesalahan $10 \%$ adalah sebanyak 51 penghuni. Teknik sampel yang digunakan yaitu Accidental Sampling yang mana teknik ini penentuan sampelnya berdasarkan kebetulan, sehingga siapa saja yang secara kebetulan ditemui oleh peneliti digunakan sebagai sampel bila orang yang ditemui tersebut sesuai dengan sumber data yang dibutuhkan.

Adapun penilaian observatif dalam penelitian ini adalah peneliti melakukan observasi langsung di lapangan dan memberikan penilaian terhadap kondisi fisik bangunan rumah susun. Proses penilaian ini dilakukan dengan memberi skor pada setiap komponen kondisi fisik rumah yang terkait dengan indikator komponen masing-masing (Bria, 2015). Penilaian dilakukan dengan pemberian skor sebagai berikut:

- Sangat Nyaman (skor 5) yaitu komponen yang ada melebihi dengan indikator;

- Nyaman (skor 4) yaitu komponen yang ada sesuai dengan indikator;

- Cukup Nyaman (skor 3) yaitu komponen yang ada mendekati indikator;

- $\quad$ Tidak Nyaman (skor 2) yaitu komponen yang ada jauh di bawah indikator;

- Sangat Tidak Nyaman (skor 1) yaitu tidak terdapat komponen yang dimaksud.

\section{HASIL DAN PEMBAHASAN}

\subsection{Identifikasi Persepsi Penghuni Terhadap Kenyamanan Tinggal Di Rumah Susun Sederhana Sewa}

Identifikasi persepsi penghuni dilakukan berdasarkan indikator yang sudah ada dan setiap indikator memiliki nilai yang mana nilai-nilai tersebut akan di gabungkan berdasarkan variabelnya lagi. Setelah nilai tersebut di gabungkan maka akan mendapat nilai tiap variabel.

a. Kecukupan dan Kualitas Ruang

Variabel kecukupan dan kualitas ruang terdiri dari 4 item yaitu, daya tampung ruang, kepadatan ruang, sirkulasi udara dan kebersihan lingkungan (tabel 2).

Tabel 2. Penilaian Variabel Kecukupan dan Kualitas Ruang

\begin{tabular}{|c|c|c|c|c|c|c|}
\hline \multirow[b]{2}{*}{ No. } & \multirow[b]{2}{*}{ Pernyataan } & \multicolumn{5}{|c|}{ Jumlah Jawaban Responden } \\
\hline & & $\begin{array}{l}\text { Sangat } \\
\text { Nyaman } \\
\text { (responden) }\end{array}$ & $\begin{array}{l}\text { Nyaman } \\
\text { (responden) }\end{array}$ & $\begin{array}{l}\text { Cukup } \\
\text { Nyaman } \\
\text { (responden) }\end{array}$ & $\begin{array}{l}\text { Tidak } \\
\text { Nyaman } \\
\text { (responden) }\end{array}$ & $\begin{array}{l}\text { Sangat } \\
\text { Tidak } \\
\text { Nyaman } \\
\text { (responden) }\end{array}$ \\
\hline 1. & $\begin{array}{l}\text { Daya tampung } \\
\text { ruang }\end{array}$ & 4 & 26 & 20 & 1 & 0 \\
\hline 2. & $\begin{array}{l}\text { Kepadatan } \\
\text { ruang }\end{array}$ & 1 & 24 & 20 & 6 & 0 \\
\hline 3. & Sirkulasi udara & 0 & 23 & 13 & 14 & 1 \\
\hline 4. & $\begin{array}{l}\text { Kebersihan } \\
\text { lingkungan }\end{array}$ & 1 & 17 & 26 & 6 & 1 \\
\hline \multicolumn{2}{|c|}{$\begin{array}{l}\text { Jumlah jawaban } \\
\text { responden }\end{array}$} & 6 & 90 & 79 & 27 & 2 \\
\hline \multicolumn{2}{|c|}{ Jumlah nilai bobot } & 30 & 360 & 237 & 54 & 2 \\
\hline \multicolumn{2}{|c|}{ Total } & 683 & & & & \\
\hline
\end{tabular}

Nilai tertinggi $=$ Jumlah responden $\mathrm{x}$ jumlah item $\mathrm{x}$ nilai bobot tertinggi

$$
\begin{aligned}
& =51 \times 4 \times 5 \\
& =1.020
\end{aligned}
$$

Nilai terendah $=$ Jumlah responden $\mathrm{x}$ jumlah item $\mathrm{x}$ nilai bobot terendah 


$$
\begin{aligned}
& =51 \times 4 \times 1 \\
& =204
\end{aligned}
$$

Nilai antara $=\frac{\text { Nilai tertinggi }- \text { Nilai terendah }}{5}$

$$
\begin{aligned}
& =\frac{1020-204}{5} \\
& =163,2
\end{aligned}
$$

Keterangan :

Sangat Nyaman $\quad=856,8-1020$

Nyaman $\quad=693,6-856,8$

Cukup Nyaman $\quad=530,4-693,6$

Tidak Nyaman $\quad=367,2-530,4$

Sangat Tidak Nyaman $=204-367,2$

Dari hasil analisis diatas untuk variabel kecukupan dan kualitas ruang yang terdiri dari 4 item tersebut, berarti nilai tertinggi 1020, nilai terendah 204 dan nilai antara 163,2. Tabel 2 menunjukkan bahwa nilai akhir untuk indikator kecukupan dan kualitas ruang yaitu 683. Nilai tersebut menunjukkan bahwa memperoleh nilai atau pendapat Cukup Nyaman karena berada pada kategori 530,4 - 693,6. Artinya nilai Cukup Nyaman tersebut memiliki bobot 3.

b. Lokasi

\begin{tabular}{|c|c|c|c|c|c|c|}
\hline \multirow[b]{2}{*}{ No. } & \multirow[b]{2}{*}{ Pernyataan } & \multicolumn{5}{|c|}{ Jumlah Jawaban Responden } \\
\hline & & $\begin{array}{l}\text { Sangat } \\
\text { Nyaman } \\
\text { (responden) }\end{array}$ & $\begin{array}{l}\text { Nyaman } \\
\text { (responden) }\end{array}$ & $\begin{array}{l}\text { Cukup } \\
\text { Nyaman } \\
\text { (responden) }\end{array}$ & $\begin{array}{l}\text { Tidak } \\
\text { Nyaman } \\
\text { (responden) }\end{array}$ & $\begin{array}{l}\text { Sangat } \\
\text { Tidak } \\
\text { Nyaman } \\
\text { (responden) }\end{array}$ \\
\hline 1. & Jarak ke sarana & 2 & 35 & 14 & 0 & 0 \\
\hline 2. & Bebas polusi & 2 & 18 & 24 & 5 & 2 \\
\hline 3. & Aksesbilitas & 3 & 34 & 13 & 1 & 0 \\
\hline 4. & Jarak ke tempat bekerja & 1 & 25 & 24 & 1 & 0 \\
\hline \multicolumn{2}{|c|}{ Jumlah jawaban responden } & 8 & 112 & 75 & 7 & 2 \\
\hline \multicolumn{2}{|c|}{ Jumlah nilai bobot } & 40 & 448 & 225 & 14 & 2 \\
\hline \multicolumn{2}{|c|}{ Total } & 729 & & & & \\
\hline
\end{tabular}

Variabel lokasi terdiri dari 4 item yaitu jarak ke sarana, bebas polusi, aksesbilitas, dan jarak ke tempat bekerja (tabel 3).

Tabel 3. Penilaian Variabel Lokasi

Sumber : Hasil Analisis, 2020

Nilai tertinggi $=$ Jumlah responden $\mathrm{x}$ jumlah item $\mathrm{x}$ nilai bobot tertinggi

$$
\begin{aligned}
& =51 \times 4 \times 5 \\
& =1.020
\end{aligned}
$$

Nilai terendah $=$ Jumlah responden $\mathrm{x}$ jumlah item $\mathrm{x}$ nilai bobot terendah

$$
=51 \times 4 \times 1
$$$$
=204
$$

Nilai antara $=\frac{\text { Nilai tertinggi }- \text { Nilai terendah }}{5}$

$$
\begin{aligned}
& =\frac{1020-204}{5} \\
& =163,2
\end{aligned}
$$

Keterangan :

Sangat Nyaman

Nyaman

$$
\begin{aligned}
& =856,8-1020 \\
& =693,6-856,8
\end{aligned}
$$


Cukup Nyaman $=530,4-693,6$

Tidak Nyaman $\quad=367,2-530,4$

Sangat Tidak Nyaman $=204-367,2$

Dari hasil analisis $\mathrm{d}$ atas untuk variabel lokasi yang terdiri dari 4 item tersebut, berarti nilai tertinggi 1020, nilai terendah 204 dan nilai antara 163,2. Tabel di atas menunjukkan bahwa nilai akhir untuk indikator kecukupan dan kualitas ruang yaitu 729. Nilai tersebut menunjukkan bahwa memperoleh nilai atau pendapat Nyaman karena berada pada kategori 693,6 - 856,8. Artinya nilai Nyaman tersebut memiliki bobot 4 .

\section{c. Prasarana}

Variabel prasarana teridiri dari 10 item yaitu jalan, air bersih, listrik, air limbah, persampahan, telekomunikasi, tangga utama, pintu dan tangga darurat, ruang berkumpul dan parkir (tabel 4).

Tabel 4. Penilaian Variabel Prasarana

\begin{tabular}{|c|c|c|c|c|c|c|}
\hline \multirow[b]{2}{*}{ No. } & \multirow[b]{2}{*}{ Pernyataan } & \multicolumn{5}{|c|}{ Jumlah Jawaban Responden } \\
\hline & & $\begin{array}{l}\text { Sangat } \\
\text { Nyaman } \\
\text { (responden) }\end{array}$ & $\begin{array}{l}\text { Nyaman } \\
\text { (responden) }\end{array}$ & $\begin{array}{l}\text { Cukup } \\
\text { Nyaman } \\
\text { (responden) }\end{array}$ & $\begin{array}{l}\text { Tidak } \\
\text { Nyaman } \\
\text { (responden) }\end{array}$ & $\begin{array}{l}\text { Sangat } \\
\text { Tidak } \\
\text { Nyaman } \\
\text { (responden) }\end{array}$ \\
\hline 1. & Jalan & 3 & 31 & 15 & 2 & 0 \\
\hline 2. & Air bersih & 6 & 22 & 20 & 3 & 0 \\
\hline 3. & Listrik & 4 & 25 & 17 & 5 & 0 \\
\hline 4. & Air limbah & 4 & 13 & 13 & 17 & 4 \\
\hline 5. & Persampahan & 9 & 30 & 10 & 2 & 0 \\
\hline 6. & Telekomunikasi & 3 & 27 & 18 & 3 & 0 \\
\hline 7. & Tangga utam & 0 & 23 & 23 & 5 & 0 \\
\hline 8. & $\begin{array}{lll}\text { Pintu dan } & \text { tangga } \\
\text { darurat } & & \\
\end{array}$ & 2 & 22 & 25 & 2 & 0 \\
\hline 9. & Ruang berkumpul & 3 & 18 & 28 & 2 & 0 \\
\hline 10. & Parkir & 2 & 29 & 16 & 4 & 0 \\
\hline Jum & ah jawaban responden & 36 & 240 & 185 & 44 & 4 \\
\hline Jum & ah nilai bobot & 180 & 960 & 555 & 88 & 4 \\
\hline Tota & & 1787 & & & & \\
\hline
\end{tabular}

Sumber : Hasil Analisis, 2020

Nilai tertinggi $=$ Jumlah responden $\times$ jumlah item $\times$ nilai bobot tertinggi

$$
\begin{aligned}
& =51 \times 10 \times 5 \\
& =2550
\end{aligned}
$$

Nilai terendah $=$ Jumlah responden $\times$ jumlah item $\times$ nilai bobot terendah

$$
\begin{aligned}
& =51 \times 10 \times 1 \\
& =510
\end{aligned}
$$

Nilai antara $=\frac{\text { Nilai tertinggi }- \text { Nilai terendah }}{5}$

$$
\begin{aligned}
& =\frac{2550-510}{5} \\
& =408
\end{aligned}
$$

Keterangan :

$$
\begin{array}{lr}
\text { Sangat Nyaman } & =2142-2550 \\
\text { Nyaman } & =1734-2142 \\
\text { Cukup Nyaman = 1326 }- & 1734
\end{array}
$$


Tidak Nyaman $\quad=918-1326$

Sangat Tidak Nyaman $=510-918$

Dari hasil analisis diatas untuk variabel prasarana yang terdiri dari 10 item tersebut, berarti nilai tertinggi 2550, nilai terendah 250 dan nilai antara 408. Tabel di atas menunjukkan bahwa nilai akhir untuk indikator kecukupan dan kualitas ruang yaitu 1787. Nilai tersebut menunjukkan bahwa memperoleh nilai atau pendapat Nyaman karena berada pada kategori 1734 - 2142. Artinya nilai Nyaman tersebut memiliki bobot 4 .

\section{d.Sarana}

Variabel sarana terdiri dari 4 item yaitu tempat bermain anak, fasilitas peribadatan, fasilitas perdagangan dan fasilitas olahraga (tabel 5).

Tabel 5. Penilaian Variabel Sarana

\begin{tabular}{|c|c|c|c|c|c|c|}
\hline \multirow[b]{2}{*}{ No. } & \multirow[b]{2}{*}{ Pernyataan } & \multicolumn{5}{|c|}{ Jumlah Jawaban Responden } \\
\hline & & $\begin{array}{l}\text { Sangat } \\
\text { Nyaman } \\
\text { (responden) }\end{array}$ & $\begin{array}{l}\text { Nyaman } \\
\text { (responden) }\end{array}$ & $\begin{array}{l}\text { Cukup } \\
\text { Nyaman } \\
\text { (responden) }\end{array}$ & $\begin{array}{l}\text { Tidak } \\
\text { Nyaman } \\
\text { (responden) }\end{array}$ & $\begin{array}{l}\text { Sangat } \\
\text { Tidak } \\
\text { Nyaman } \\
\text { (responden) }\end{array}$ \\
\hline 1. & Tempat bermain anak & 2 & 19 & 21 & 8 & 1 \\
\hline 2. & Fasilitas peribadatan & 4 & 23 & 16 & 7 & 1 \\
\hline 3. & Fasilitas perdagangan & 2 & 19 & 18 & 11 & 1 \\
\hline 4. & Fasilitas olahraga & 3 & 17 & 19 & 11 & 1 \\
\hline \multicolumn{2}{|c|}{ Jumlah jawaban responden } & 11 & 78 & 74 & 37 & 4 \\
\hline \multicolumn{2}{|c|}{ Jumlah nilai bobot } & 55 & 312 & 222 & 74 & 4 \\
\hline \multicolumn{2}{|c|}{ Total } & 667 & & & & \\
\hline
\end{tabular}

Sumber : Hasil Analisis, 2020

Nilai tertinggi $=$ Jumlah responden $\mathrm{x}$ jumlah item $\mathrm{x}$ nilai bobot tertinggi

$$
\begin{aligned}
& =51 \times 4 \times 5 \\
& =1.020
\end{aligned}
$$

Nilai terendah $=$ Jumlah responden $\mathrm{x}$ jumlah item $\mathrm{x}$ nilai bobot terendah

$$
\begin{aligned}
& =51 \times 4 \times 1 \\
& =204
\end{aligned}
$$

Nilai antara $=\frac{\text { Nilai tertinggi }- \text { Nilai terendah }}{5}$

$$
\begin{aligned}
& =\frac{1020-204}{5} \\
& =163,2
\end{aligned}
$$

Keterangan :

$$
\begin{array}{ll}
\text { Sangat Nyaman } & =856,8-1020 \\
\text { Nyaman } & =693,6-856,8 \\
\text { Cukup Nyaman = 530,4 } & -693,6 \\
\text { Tidak Nyaman } & =367,2-530,4 \\
\text { Sangat Tidak Nyaman } & =204-367,2
\end{array}
$$

Dari hasil analisis variabel sarana yang terdiri dari 4 item tersebut, berarti nilai tertinggi 1020, nilai terendah 204 dan nilai antara 163,2. Tabel di atas menunjukkan bahwa nilai akhir untuk indikator kecukupan dan kualitas ruang yaitu 667. Nilai tersebut menunjukkan bahwa memperoleh nilai atau pendapat Cukup Nyaman karena berada pada kategori 530,4 - 693,6. Artinya nilai Cukup Nyaman tersebut memiliki bobot 3 . 
3.2. Rekapitulasi Persepsi Penghuni Terhadap Kenyamanan Tinggal Di Rumah Susun Sederhana Sewa

Analisis persepsi penghuni terhadap kenyaman tinggal di rumah susun sederhana sewa terdiri dari 4 variabel, yaitu kecukupan dan kualitas ruang, lokasi, prasarana, dan sarana. Setiap variable sudah memiliki nilai masing-masing berdasarkan hasil analisis per variable. Tabel 6 berikut merupakan hasil penilaian analisis berdasarkan seluruh indikator yang digunakan.

Tabel 6. Rekapitulasi Persepsi Penghuni

\begin{tabular}{lll}
\hline No. & Komponen Indikator & Nilai \\
\hline 1. & Kecukupan dan kualitas ruang & 3 \\
\hline 2. & Lokasi & 4 \\
\hline 3. & Prasarana & 4 \\
\hline 4. & Sarana & 3 \\
\hline Jumlah & 14 \\
\hline
\end{tabular}

Sumber : Hasil Analisis, 2020

Nilai tertinggi $=$ Jumlah komponen $\times$ nilai tertinggi

$$
\begin{aligned}
& =4 \times 5 \\
& =20
\end{aligned}
$$

Nilai terendah $=$ Jumlah komponen $\mathrm{x}$ nilai terendah

$$
\begin{aligned}
& =4 \times 1 \\
& =4
\end{aligned}
$$

Nilai antara $=\frac{\text { Nilai tertinggi }- \text { Nilai terendah }}{5}$

$$
\begin{aligned}
=\frac{20-4}{5} & \\
& =3.2
\end{aligned}
$$

Keterangan :

$$
\begin{array}{ll}
\text { Sangat Nyaman } & =16,8-20 \\
\text { Nyaman } & =13,6-16,8
\end{array}
$$

Cukup Nyaman $=10,4-13,6$

Tidak Nyaman $\quad=7,2-10,4$

Sangat Tidak Nyaman $=4-7,2$

Dari hasil analisis di atas untuk 4 variabel yang diteliti, tabel di atas menunjukkan bahwa untuk skor persepsi penghuni adalah 14. Skor tersebut menunjukkan bahwa nilai atau pendapat Nyaman karena berada pada kategori 13,6 - 16,8.

\subsection{Merumuskan Tingkat Kenyamanan Hunian Di Rumah Susun Sederhana Sewa}

Analisis tingkat kenyamanan hunian menggunakan 2 jenis komponen dengan setiap variabel mempunyai nilai Sangat Nyaman dengan skor 5 dan nilai Sangat Tidak Nyaman dengan skor 1 . Untuk kesimpulan hasil analisis, penentuan range antara Sangat Nyaman dan Sangat Tidak Nyaman berdasarkan jumlah skor maksimal dan minimal. Dengan jumlah komponen yang di analisis ada 2, maka untuk skor maksimalnya adalah 10, skor minimal adalah 2, dan skor antara 1,6. Berikut tabel 7 mrupakan hasil penelitian analisis berdasarkan seluruh variabel yang digunakan.

Tabel 7. Tingkat Kenyamanan Hunian

\begin{tabular}{lll}
\hline No. & Komponen & Nilai \\
\hline $\mathbf{1 .}$ & Kondisi Fisik Hunian & 4 \\
\hline 2. & Persepsi Penghuni & 4 \\
\hline Jumlah & & 8 \\
\hline
\end{tabular}

Sumber : Hasil Analisis, 2020 
Nilai tertinggi $=$ Jumlah komponen $\times$ nilai tertinggi

$$
\begin{aligned}
& =2 \times 5 \\
& =10
\end{aligned}
$$

Nilai terendah $=$ Jumlah komponen $\times$ nilai terendah

$$
=2 \times 1
$$

$=2$

Nilai antara $=\frac{\text { Nilai tertinggi }- \text { Nilai terendah }}{5}$

$$
\begin{aligned}
& =\frac{10-2}{5} \\
& =1,6
\end{aligned}
$$

Keterangan :

Sangat Nyaman $\quad=8,4-10$

Nyaman $\quad=6,8-8,4$

Cukup Nyaman $=5,6-6,8$

Tidak Nyaman $\quad=3,6-5,2$

Sangat Tidak Nyaman $=2-3,6$

Dari hasil analisis di atas untuk 4 variabel yang diteliti pada tabel 7 menunjukkan bahwa untuk skor Tingkat Kenyamanan Penghuni adalah 8. Skor menunjukkan bahwa nilai tersebut berada di kategori Nyaman karena berada pada kategori 6,8-8,4. Nilai tersebut bisa berada di kategori nyaman di karenakan warga atau penghuni yang tinggal di rumah susun sudah merasa nyaman tinggal disana bertahun-tahun biarpun dengan secara kondisi ada beberapa yang kurang baik seperti kondisi lingkungan yang kotor dikarenakan kurang sadarnya akan kebersihan lingkungan. Padahal kebersihan lingkungan sangat berpengaruh terhadap kehidupan manusia sehari-sehari karena jika lingkungan kotor bisa menyebabkan penyakit yang mana semua orang bisa terjangkit.

\section{KESIMPULAN}

Nilai akhir untuk sasaran pertama yaitu 14 yang mana nilai tersebut termasuk ke dalam kategori Nyaman. Pada saat observasi langsung tidak semua indikator mendapatkan nilai yang rendah tetapi ada juga yang mendapatkan nilai yang tinggi, sehingga pada saat penjumlahan secara keseluruhan nilai tinggi tersebut dapat menutupi indikator yang mendapat nilai rendah. Nilai akhir untuk sasaran kedua yaitu 14 yang mana nilai tersebut termasuk ke dalam kategori Nyaman. Untuk mendapatkan nilai akhir untuk sasaran kedua ini di perlukannya penilaian dari masyarakat itu sendiri yang tinggal di rumah susun tersebut. Setiap masyarakat memiliki pendapat yang berbeda-beda untuk menilai setiap indikator yang ada. Untuk mendapatkan nilai akhir dari sasaran ketiga ini diperlukannya nilai akhir dari sasaran pertama dan nilai akhir dari sasaran kedua. Setelah mendapatkan nilai dari 2 sasaran tersebut maka nilai akhir untuk sasaran ketiga adalah 8 yang mana nilai tersebut masuk ke dalam kategori Nyaman.

\section{DAFTAR PUSTAKA}

Badan Pusat Statistik. Kota Pontianak Dalam Angka. Tahun 2019

Fredika Trivoni Bria, 2015, Tingkat Kenyamanan Hunian Berdasarkan Kondisi Fisik Rumah Susun Kuto Beda. Kepmen Kesehatan No. 829/Menkes/SK/VII/1999 tentang Persyaratan Kesehatan Rumah Tinggal Kepmen Kimpraswil No.403/KPTS/M/2002 tentang Pedoman Teknis Pembangunan Rumah Lily Mauliani, 2002, Rumah Susun Sebagai Alternatif Penyediaan Perumahan Bagi Masyarakat Golongan Menengah Bawah, Jurnal Arsitektur, Vol.1. No.Perdana

Luthfiah, 2010, Perubahan Bentuk dan Fungsi Hunian Pada Rumah Susun Pasca Penghunian, Jurnal Ruang, Vol.2. No.2. Hal.36

Sugiyono, 2011, Metode Penelitian Kuantitatif Kualitatif dan R\&D, Penerbit : Alfabeta, Bandung, Hal.80,93,142,145-146

Undang-Undang RI No. 20 Tahun 2011 tentang Rumah Susun 